\title{
Farmers' Perception of the Decade-Long Grazing Ban Policy in Northern China: A Case Study of Yanchi County
}

\author{
Yong Chen ${ }^{1, *}$ and Lihua Zhou ${ }^{2}$ \\ 1 Cold and Arid Regions Environmental and Engineering Research Institute, Chinese Academy of Sciences, \\ Lanzhou 730000, China \\ 2 Institutes of Science and Development, Chinese Academy of Sciences, Beijing 100190, China; \\ lihuazhou@lzb.ac.cn \\ * Correspondence: chenyong@lzb.ac.cn
}

Academic Editor: Marc A. Rosen

Received: 16 May 2016; Accepted: 25 October 2016; Published: 30 October 2016

\begin{abstract}
This study analyzes farmers' perception of grazing restriction policies, grassland environment and ecological management following the implementation of environmental protection policies in northern China. Understanding farmers' attitudes and their causes will hopefully aid in the creation and execution of future policies. One hundred and thirty-five households were surveyed at three occasions over the course of a decade to explore the causes and processes of farmers' perception. Farmers' ecological awareness tends to be short term. In areas with a degraded environment, farmers were eager to implement policies to improve the environment and recognized the positive impact of the grazing ban policy (GBP). However, as conditions improved, farmers' recognition and acceptance of the GBP became negative. Although farmers recognized the benefits of the GBP, they showed little awareness of the long-term process of environmental governance. As can be seen from the farmers' ecological awareness and their attitudes toward the GBP, they are more inclined to value short-term economic interest than ecological protection. We suggest that good environmental protection policy must take into account the ecological and economic interests of farmers.
\end{abstract}

Keywords: perception; attitudes; awareness; grazing ban policy; Yanchi County

\section{Introduction}

As one of the globally important terrestrial ecosystems, grasslands provide livelihoods for nearly 800 million people and are a crucial source of livestock forage and wildlife habitat [1]. With recent climate change, rapid population growth, and land-use and cover changes, three quarters of the world's grasslands have been degraded and more than $25 \%$ of their animal support capacity has been lost [2].

The degradation of China's grasslands began to accelerate after the 1950s [3]. In addition to climate, population, land use, and other driving factors, major policies in China have had a more prominent impact on grassland environments than in other regions of the world. Before the founding of the People's Republic of China, there were no clear policy constraints on farmers' grassland management. Because grasslands were sparsely populated, farmers usually adopted a nomadic mode of production [4]. At that time, grasslands experienced less pressure, and their natural productivity and self-recovery capability maintained ecosystem equilibrium [5,6]. During the period of 1950-1978, with the founding of the People's Republic of China, the population grew rapidly. Thus, food production became one of the most important enterprises at that time. A large-scale land reclamation policy was implemented in this context [7]. As the population increased and the conflicts between arable land and grassland 
intensified, the nomadic distance gradually narrowed and slowly evolved into sedentary grazing [8]. With excessive use and lack of any protection, this led to the degradation of many grassland regions $[9,10]$. At this time, all the grassland and livestock were owned by communes. With the reform of the economic system in 1978 (the communes were replaced by a household contract responsibility system), grasslands were contracted to farmers. However, due to the higher cost of grassland fencing, most of them were not separated [11]. Therefore, this did not change the nature of the common-pool grassland management. Livestock were also distributed to households, which greatly promoted farmers' enthusiasm for production. The average number of livestock increased from $30 \times 10^{6}$ heads in 1949 to $100 \times 10^{6}$ in the 1990s. This led to an approximate $70 \%$ decrease in the average land area per head of livestock. This trend also caused the overall grassland area to decrease by $65 \times 10^{6} \mathrm{hm}^{2}$. This then led to a sharp decline in the quality of grassland. These factors created a vicious cycle of grassland degradation [12].

To curb the trend of grassland degradation and coordinate China's western development strategy, the state implemented a series of policies primarily aimed at environmental protection. The grazing ban policy (GBP) is one of these policies. In 2003, a GBP was implemented in Ningxia, Inner Mongolia, Gansu, Qinghai, Yunnan, Sichuan, Tibet, Xinjiang, and the Xinjiang Production and Construction Corps (the policy was expanded to Heilongjiang, Jilin, Liaoning, Hebei, and Shanxi in 2012). The main component of the policy is the fencing of seriously degraded grassland, in exchange for subsidies including feed grain (for five years) and capital grants (for the construction of grassland fencing, etc.) tailored to regional differences. By 2013, the total area of GBP implementation reached $0.96 \times 10^{8} \mathrm{hm}^{2}$. Following the implementation of the GBP, the grassland ecological environment significantly improved. The grassland vegetation coverage, vegetation height, and fresh yield compared with areas without grazing control are $10 \%, 34.8 \%$, and $53.5 \%$ higher, respectively.

The implementation area of the GBP is focused on China's ethnic minority areas (including Hui, Mongolian, Tibetan, and Kazak minorities) where grassland is a main source of income. The vast majority of farmers have difficulty accepting these mandatory changes to their traditional means of livelihood. Moreover, according to the survey, more than $70 \%$ of farmers engaged in illegal grazing following the GBP implementation. Therefore, understanding the attitude of farmers to the GBP and their perceptions of the environment is critically important for future conservation strategies.

Previous evaluations of new or reformed rangeland policies focused more on changes in soil physical and chemical properties [13-16], grassland community characteristics [17,18], farmers' livelihoods [19-21], and farming inputs and outputs [22,23]. Other studies used governmental or public interview data from a small number of farmers to examine the implications of policies [24,25]. However, these studies are limited to cross-sectional data for one year, and there is a lack of comparative studies over different years.

In this study, household surveys were conducted over three stages (2003-2004, 2007-2008, and 2011-2012) to explore changes in farmers' attitudes towards the GBP over time and their awareness of ecological changes after the GBP. Although there are certain discrepancies between farmers' answers and their actual behavior, farmers' attitudes toward the policy over time still reflect their behavior to a certain extent. This analysis also lays the groundwork to explore root causes of illegal grazing behavior.

The main objectives of this study are to: (1) identify how well farmers' perception reflects actual environmental change; (2) follow changes in farmers' perception over time and determine the causes of these changes; and (3) recommend improved strategies for the GBP.

\section{Materials and Methods}

\subsection{Sampling}

A typical prohibited grazing area of Yanchi County was selected for this study. Yanchi County lies in the central northern area of China, in the eastern part of the Ningxia Hui autonomous region $\left(106^{\circ} 30^{\prime} \mathrm{E}\right.$ to $107^{\circ} 47^{\prime} \mathrm{E}, 37^{\circ} 04^{\prime} \mathrm{N}$ to $38^{\circ} 10^{\prime} \mathrm{N}$ ) (Figure 1). Yanchi County covers an estimated area of $8557.7 \mathrm{~km}^{2}$. Yanchi County is a typical farming and stockbreeding area, mainly focusing on 
stockbreeding. The output value of stockbreeding accounts for $60 \%$ of the total output value of agriculture. The grassland area is $5.57 \times 10^{5} \mathrm{hm}^{2}$, of which $4.76 \times 10^{5} \mathrm{hm}^{2}$ is of suitable ecological quality for farming. Stockbreeding in Yanchi County has developed over 1000 years, and the grassland of this region was very lush according to historical records. From the 1950s to the 1980s, large areas of grassland were cleared for farmland following a series of national policies. This process, combined with an extensive pattern of continuous grazing, directly resulted in the rapid desertification of the area. By 2000, the desertified grassland area was $2.87 \times 10^{5} \mathrm{hm}^{2}$, accounting for $62.4 \%$ of the total available grassland area. To restore the grassland vegetation and reduce the grazing pressure on natural grassland, the GBP was implemented by Yanchi County in 1 November 2002, earlier than the national implementation. Under the GBP, grasslands were typically allocated to a household or group of households and most of the grasslands were fenced (unlike the previous contract responsibility system, the GBP only allows farmers to maintain, manage or mow the grassland.). To change the traditional practices of farmers, the government also implemented a series of policies to facilitate barn feeding and punish illegal grazing. Since farmers are accustomed to a continuous grazing regime, government-mandated GBP was hard to accept. Therefore, farmers often resort to illegal grazing. As government supervision is more intense during the day, farmers gradually shifted to night grazing. According to the survey, $90 \%$ of ewe-breeding farmers engaged in illegal night grazing. Farmers put up with tremendous long-term physical and psychological pressure to conduct illegal grazing, reflected in their attitudes towards the GBP. Yanchi County implemented the GBP more than a decade ago. In order to better understand changes in farmers' perception to policy and environment, the project team conducted three household surveys (in 2003-2004, 2007-2008, and 2011-2012), covering the entire county. The systematic sampling method was chosen. Based on eight towns of Yanchi County, a certain number of farmers were randomly selected according to the proportion of the population of the towns. In the space, the distribution of the selected individuals was considered to be able to satisfy the maximum degree of coverage of the township. A semi-structured survey that combined a questionnaire and household interview was used. The majority of farmers surveyed were mainly engaged in illegal grazing. These farmers are most dependent on the grassland, and they are the most impacted by the grazing ban policy. Therefore, these farmers' perception of policy and ecological environment is more clear-cut.

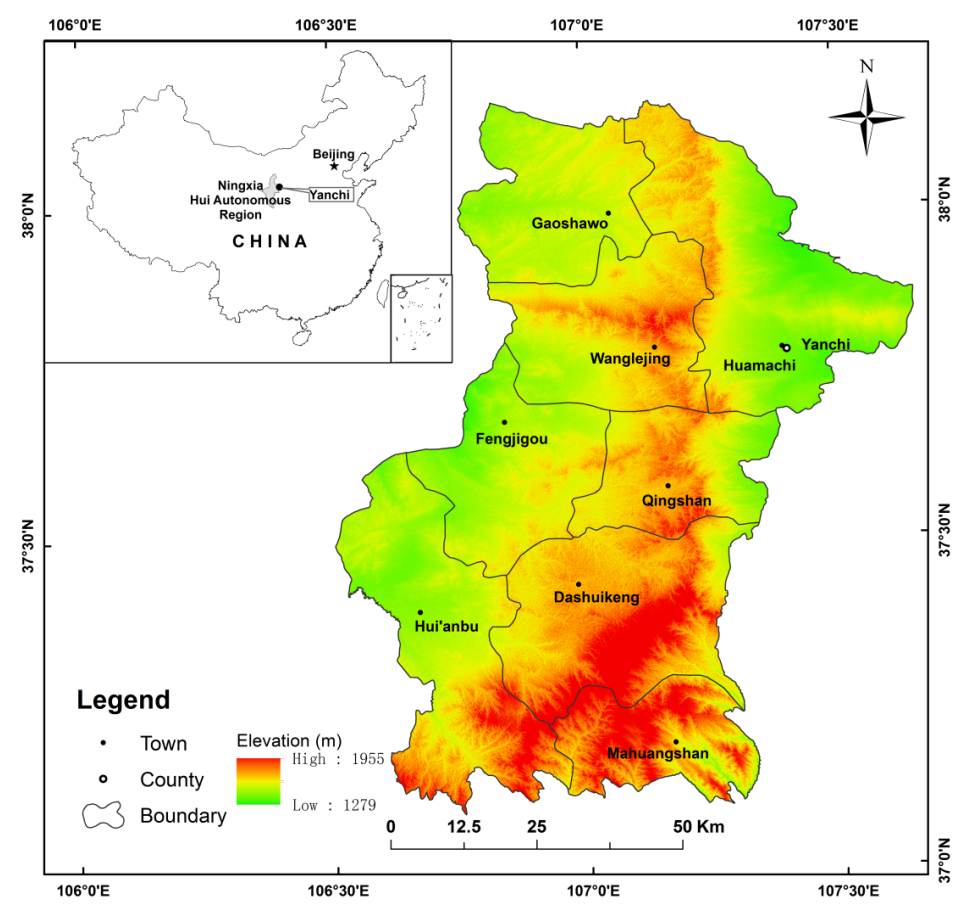

Figure 1. Location of the study area in China. 
We recorded the home address and household information of farmers during the first survey. Some individual farmers could not be investigated on return visits due to relocation, illness, death, etc. Data from these households were removed. We first investigated a total of 264 households. After removing data to preserve consistency over the years, 135 households remained in our sample (Table 1).

Table 1. Characteristics of survey respondents.

\begin{tabular}{ccccc}
\hline & Respondent Characteristic & 2003-2004 & 2007-2008 & 2011-2012 \\
\hline & Village Number & 21 & 21 & 21 \\
\hline Gender & Number of Households & 135 & 135 & 135 \\
\hline \multirow{2}{*}{ Age } & Male & $96.49 \%$ & $96.49 \%$ & $96.49 \%$ \\
& Female & $3.51 \%$ & $3.51 \%$ & $3.51 \%$ \\
\hline Education & $21-30$ & $12.33 \%$ & $3.67 \%$ & $0.67 \%$ \\
& $31-40$ & $33 \%$ & $26.67 \%$ & $16.67 \%$ \\
& $41-50$ & $26.33 \%$ & $30.33 \%$ & $34.67 \%$ \\
& $51-60$ & $19 \%$ & $24.33 \%$ & $22.67 \%$ \\
& $>61$ & $9.3 \%$ & $15 \%$ & $25.33 \%$ \\
\hline Household & Illiterate & $11.41 \%$ & $11.41 \%$ & $11.41 \%$ \\
resources & Primary school & $42.95 \%$ & $42.95 \%$ & $42.95 \%$ \\
& Middle school & $40.6 \%$ & $40.6 \%$ & $40.6 \%$ \\
& High school & $4.7 \%$ & $4.7 \%$ & $4.7 \%$ \\
& College or university & $0.34 \%$ & $0.34 \%$ & $0.34 \%$ \\
\hline & Members & 5 & 5 & 4 \\
& Agriculture population & 4 & 3 & 3 \\
& Non-agriculture population & 1 & 2 & 1 \\
& Grassland area (hm ${ }^{2}$ ) & 15.42 & 15.42 & 15.42 \\
& Cultivated area (hm ${ }^{2}$ ) & 2.16 & 1.58 & 1.93 \\
& Average annual family income (CNY) & 7429.29 & 9492.68 & $35,042.38$ \\
& Proportion of non-agriculture income & $6.93 \%$ & $33.868 \%$ & $14.47 \%$ \\
& Number of sheep & 30 & 32 & 59.41 \\
\hline
\end{tabular}

\subsection{Survey Instrument and Analytical Methods}

Survey questionnaires covered: (1) the background of interviewees (including gender, age, educational level, and occupation) and their household information (including members, grassland area, cultivated area, family income, and number of sheep); (2) perceptions of farmers towards grassland environment, including grassland environment changes after the GBP and the reasons behind grassland degradation; (3) attitudes of farmers to the GBP, including willingness to accept and the impact of the GBP on the environment; and (4) farmers' awareness of ecological management, including the significance of ecological management and how to conduct grassland ecological management.

The questionnaire used two design approaches for different content. Farmers' basic information was collected via tables completed by interviewees. The survey of the attitudes of farmers contained a series of questions with interviewees choosing amongst several possible answers. During the survey, additional questions were sometimes asked to develop particularly vivid examples.

Results were analyzed by frequency distributions and the Mann-Whitney $U$ test. The frequency distribution of each variable was obtained by calculating the frequency of various responses to each question. Mann-Whitney test is to determine whether there is a statistically significant difference in the perception of farmers in different stages by using the Mann-Whitney U statistic.

\section{Results}

\subsection{Farmers' Perceptions of the Grassland Environment}

Grassland desertification in Yanchi County was extremely serious before the implementation of the GBP. According to local farmers' descriptions, "The wind blew all year, from winter to spring." 
The beginning of the GBP was marked by a series of government initiatives, including reseeding and planting of grass. In total, $51.79 \%$ of Yanchi County farmers perceived an improvement in the grassland environment (Table 2). With the extension of the GBP, grassland ecology further improved. According to vegetation surveys in Yanchi County carried out by the Agriculture and Animal Husbandry Bureau in 2009, the average height of the grassland community was approximately $30 \mathrm{~cm}$; vegetation coverage increased from $30 \%$ to $68 \%$; fresh yield increased from 720 to $2205 \mathrm{~kg} \cdot \mathrm{hm}^{-2}$; and grazing capacity increased from 2.07 to $1.33 \mathrm{hm}^{2} \cdot \mathrm{sheep}^{-1}$ unit. An increased number of farmers perceived these changes as "a little improvement" or "greatly improved" since 2007 (Table 2). The proportion which perceived a deterioration in the ecological environment, including "a little deterioration" and "great deterioration", declined correspondingly (Table 2). The Mann-Whitney U test showed that there were significant differences between the first and the last two stages, respectively $(p<0.01)$ (Table A1). However, there were no statistically significant differences between the last two stages $(p=0.541)$ (Table A1). It just showed that the degraded grassland recovered fast at the beginning of the reduction of grassland pressure. However, with the extension of the GBP, the rate of grassland recovery slowed down.

The combined findings of the three surveys indicate that farmers give considerable recognition $(82.07 \%)$ to the grassland environment improvements brought about by the GBP, while the change in perception regarding the grassland ecological environment is in line with local conditions (Table 2).

Table 2. Survey responses to the question: "What changes do you feel have happened to the grassland environment after GBP?".

\begin{tabular}{cccc}
\hline Options & 2003-2004 & 2007-2008 & 2011-2012 \\
\hline Greatly improved & $14.29 \%$ & $51.96 \%$ & $53.71 \%$ \\
A little improvement & $51.79 \%$ & $34.63 \%$ & $39.81 \%$ \\
Not improved & $17.84 \%$ & $6.49 \%$ & $4.63 \%$ \\
A little deterioration & $1.79 \%$ & $3.46 \%$ & $1.39 \%$ \\
Great deterioration & $14.29 \%$ & $3.46 \%$ & $0.46 \%$ \\
\hline
\end{tabular}

In the first two surveys following the GBP, farmers responded that overgrazing $(41.39 \%$ and $41.86 \%)$ and climate $(24.24 \%$ and $28.47 \%$ ) were the main reasons for the deterioration in the grassland environment (Table 3). However, as the grassland environment improved, farmers generally thought that long-term implementation of the GBP was not conducive to grassland renewal. The government maintained the status quo of the GBP, ignoring the use value of grassland. Therefore, at this stage, farmers attributed grassland ecological deterioration to "dry climate" and "government mismanagement" (Table 3). Before the GBP, the grasslands of Yanchi County lacked any management, resulting in a large number of unauthorized reclamations of arable land and excessive licorice digging. Therefore, farmers highlighted "reckless land reclamation" (14\%) in the early period of the GBP implementation (Table 3). As the government started to enforce appropriate regulatory measures, farmers' concerns about this behavior decreased (8.62\%) (Table 3). However, continued economic development, expansion of urban areas, and governmental promotion of breeding parks (which occupy a large area of grassland) resulted in farmer discontent (17.46\%) (Table 3). Yanchi County has a relative shortage of water resources. The grassland in the northern part of the county experienced salinization in recent years due to over-watering, which explains the $5.97 \%$ and $5.13 \%$ respondents concerned about overpumping (Table 3). There is no excessive groundwater extraction phenomenon in other areas. Although there are some differences in farmers' responses, there are no statistically significant differences between the three stages (Table A2). However, from the overall results it could be seen that farmers are more inclined to think the main reason for grassland degradation is people's irrational use of grassland. 
Table 3. Survey responses to the question: "What do you feel caused the past deterioration of grassland?".

\begin{tabular}{cccc}
\hline Options & $\mathbf{2 0 0 3 - 2 0 0 4}$ & $\mathbf{2 0 0 7 - 2 0 0 8}$ & $\mathbf{2 0 1 1 - 2 0 1 2}$ \\
\hline Government mismanagement & $17.30 \%$ & $12.52 \%$ & $23.73 \%$ \\
Overgrazing & $41.39 \%$ & $41.86 \%$ & $20.98 \%$ \\
Reckless land reclamation & $14.00 \%$ & $8.62 \%$ & $17.46 \%$ \\
Dry climate & $24.24 \%$ & $28.47 \%$ & $32.70 \%$ \\
Overpumping & $3.00 \%$ & $5.97 \%$ & $5.13 \%$ \\
Do not know & $0.07 \%$ & $2.56 \%$ & $0.00 \%$ \\
\hline
\end{tabular}

\subsection{Farmers' Attitude towards the GBP and Its Impact}

Over the study period, farmers' acceptance of the GBP changed from high to low (Table 4). At the beginning of the GBP, the most common attitude was of "voluntary acceptance, initiative implementation" (55.14\%), with the lowest proportion "firmly opposed, refused to perform" (Table 4). Moreover, this result showed significant differences with the other two stages $(p<0.01)$ (Table A3). This may be due to long-term damage by wind and sand before the GBP, making farmers eager to improve the ecological environment. Coupled with accompanying preferential agricultural subsidies, this resulted in farmers having a high expectation of the GBP. With the implementation of the GBP, the grassland ecological environment gradually improved and the impact of sand on the life of farmers decreased. Combined with lower rates of household returns after the GBP, farmers began to desire an appropriate relaxation of the GBP. At this stage, the farmers' "voluntary" ratio decreased $(37.39 \%)$, while "refused to perform" attitudes were highest (19.57\%) (Table 4). With continuing implementation of the GBP, farmers became acclimatized to illegal grazing. At this stage, farmers became indifferent to the provisions of the policy, and mainly acted according to "government regulations, forced to accept" (76.53\%) (Table 4). This result showed no statistically significant difference with the second stage $(p=0.109)$ (Table A3).

Table 4. Survey responses to the question: "What is your acceptance attitude towards GBP?".

\begin{tabular}{cccc}
\hline Options & 2003-2004 & 2007-2008 & 2011-2012 \\
\hline Voluntary acceptance, initiative implementation & $55.14 \%$ & $37.39 \%$ & $14.08 \%$ \\
Government regulations, forced to accept & $44.03 \%$ & $43.04 \%$ & $76.53 \%$ \\
Firmly opposed, refused to perform & $0.83 \%$ & $19.57 \%$ & $9.39 \%$ \\
\hline
\end{tabular}

When faced with the question of the GBP impact on the environment, farmers who believe that the policies "have a very positive impact" accounted for $74.06 \%, 59.24 \%$, and $49.37 \%$, respectively (Table 5). There were significant differences between the first and the second $(p=0.032)$ and the first and the third $(p<0.01)$ stages, respectively, but there were no statistically significant differences between the second and the third stages $(p=0.093)$ (Table A4). Although showing a marked decline, overall acceptance was higher. Integrating "have a very positive impact" and "have a positive impact" options, farmers' views of the positive environmental impact of the GBP in the three stages was on average $80.51 \%$ (Table 5). This shows that farmers recognized the effects of the GBP, but this recognition declined over time, reflecting the helplessness of the farmers to alter the policy.

Table 5. Survey responses to the question: "What do you think is the impact of the GBP on the environment?".

\begin{tabular}{cccc}
\hline Options & 2003-2004 & 2007-2008 & 2011-2012 \\
\hline Have a very positive impact & $74.06 \%$ & $59.24 \%$ & $49.37 \%$ \\
Have a positive impact & $12.31 \%$ & $24.71 \%$ & $21.84 \%$ \\
Have little impact & $6.16 \%$ & $4.94 \%$ & $18.34 \%$ \\
Basically no impact & $4.98 \%$ & $9.26 \%$ & $6.65 \%$ \\
No impact & $2.49 \%$ & $1.85 \%$ & $3.80 \%$ \\
\hline
\end{tabular}




\subsection{Farmers' Awareness of Grassland Ecological Management}

Farmers' awareness of the significance of ecological environment governance is more inclined to the short-term benefits which were brought by ecological environment improvement. The proportion of "reduce sand dust, improve the quality of life" responses increased over time, and the proportion of "beautify the environment" responses also maintained a certain level (30.52\% on average) (Table 6). Over the three surveys, the average positive responses were $52.48 \%$ (Table 6). The perception of the long-term benefits of ecological environment governance did not change much over time, e.g., $31.69 \%$ on average for "benefit for future generations" (Table 6). Farmers' expectations that the government would adapt the policy to support their income decreased over time: "optimize grassland, raise income" was higher at the beginning (33.69\%) and decreased later $(5.9 \%$ and $5.82 \%)$ as these expectations were not realized (Table 6). Tests showed that, as time went on, there was a significant difference between the first and the third stages $(p<0.01)$. However, the second stage had no differences between the first $(p=0.152)$ and the third $(p=0.541)$ stages (Table A5).

Table 6. Survey responses to the question: "What do you think is the significance of grassland environment governance?".

\begin{tabular}{cccc}
\hline Options & $\mathbf{2 0 0 3 - 2 0 0 4}$ & $\mathbf{2 0 0 7 - 2 0 0 8}$ & $\mathbf{2 0 1 1 - 2 0 1 2}$ \\
\hline Reduce sand dust, improve the quality of life & $14.32 \%$ & $21.02 \%$ & $30.54 \%$ \\
Optimize grassland, raise income & $33.69 \%$ & $5.90 \%$ & $5.82 \%$ \\
Beautify the environment & $22.14 \%$ & $37.95 \%$ & $31.48 \%$ \\
Benefit for future generations & $29.60 \%$ & $34.10 \%$ & $31.38 \%$ \\
No significance & $0.25 \%$ & $1.03 \%$ & $0.78 \%$ \\
\hline
\end{tabular}

In response to this question, no differences were found between the three stages (Table A6). Regarding grassland ecological management, farmers firstly agreed that the government should invest more $(41.67 \%, 40.52 \%$, and $41.84 \%$ ) (Table 7$)$. Secondly, they thought that "rotational grazing" should be implemented in grasslands $(20.01 \%, 41.48 \%$, and $27.61 \%)$ (Table 7$)$. The proportion supporting rotational grazing was higher in 2007-2008 for similar reasons to the farmers' acceptance of the GBP. With the improvement of the ecological environment, some farmers even thought that "the grasslands will self-restore" and that there is no need to carry out any ecological restoration. This reflects, to some extent, the farmers' dependency on grassland utilization and related income. Farmers' enthusiasm for the household contract responsibility system was not high, mainly because they expected the responsibility of grassland management to revert to them after some time (19.05\%) (Table 7). Farmers who were acclimatized to illegal grazing expected a contract responsibility system to be implemented (13.27\%) (contracted to a single household) (Table 7). However, the government only allows farmers to mow grassland, so farmers' enthusiasm decreased (12\%) (Table 7).

Table 7. Survey responses to the question: "How do you think we should conduct the grassland ecological management?".

\begin{tabular}{cccc}
\hline Options & $\mathbf{2 0 0 3 - 2 0 0 4}$ & $\mathbf{2 0 0 7 - 2 0 0 8}$ & $\mathbf{2 0 1 1 - 2 0 1 2}$ \\
\hline Government to invest & $41.67 \%$ & $40.52 \%$ & $41.84 \%$ \\
Implementation of contract responsibility system & $19.05 \%$ & $12.00 \%$ & $13.27 \%$ \\
Without governance, the grassland will self-restore & $0.03 \%$ & $0.00 \%$ & $5.06 \%$ \\
Continue GBP & $14.29 \%$ & $3.96 \%$ & $9.66 \%$ \\
Rotational grazing & $20.01 \%$ & $41.48 \%$ & $27.61 \%$ \\
Do not know & $4.95 \%$ & $2.04 \%$ & $2.56 \%$ \\
\hline
\end{tabular}

\section{Discussion}

The development of an effective policy requires understanding the background and structure of the policy as well as considering the role of the main body of people affected. Effective incentives and 
management mechanisms support the implementation of the policy. Because of their high dependency on grassland, changes in rights of use directly affect farmers' production and lifestyle. Therefore, all aspects of grassland ecosystem management should be considered when developing a grassland policy, including grasses, animals, and human beings.

In recent years, in the study of grassland resource management, adaptive management and community management have gradually garnered more attention [26-29]. These management regimes emphasize the role of resource utilization participants at different levels. The participation of the people cannot be separated from their perception and understanding of the ecological environment. Environmental perception is the psychological basis of people's environmental behavior, and proper environmental perception is the foundation of reasonable environmental behavior [30]. As the most important economic entities and the most basic decision-making units, the farmers' perceptions and attitudes towards the environment reflect the changes and functions of the regional development.

Atteh (1984) [31] showed that Nigerian farmers' perceptions of the environment are very good, and they have a strong ability to identify pest problems and consciously conduct efficient management and decisions according to the perception of pests. Gasson and Potter (1988) [32] found that if farmers have strong ecological protection awareness, their protective behavior is stronger. Whitby (1994) [33] pointed out that participation in environmental planning helped farmers change their attitude towards the environment.

This study shows that farmers' perceptions of ecological environment improvement are accurate, but they have wide-ranging comments on the GBP. According to the survey, the sheep breeding rate was higher during barn feeding than grazing periods, and the rate of return increased to a certain extent. However, farmers focused on short-term cost reduction and did not consider that after the grazing ban was lifted, the sheep breeding rate would decline to the level of the past. Thus, farmers' perceptions of the ecological environment are closely related to their economic interests and show a certain short-term bias. Cary and Wilkinson (1997) [34] showed that farmers' environmental awareness does not translate into specific environmental protection behavior unless the behavior has corresponding economic benefits. The grassland utilization behavior follows, to a certain extent, the theory of the Tragedy of the Commons [35].

Most ecological protection projects cannot immediately produce economic benefits (there are many uncertainties about the future of the project), and it is not difficult to understand why the majority of farmers with a positive environmental attitude conduct illegal grazing. Farmers have self-awareness of the illegal grazing behavior. Most of them think that the GBP policy should not be endless and that grasslands should be grazed appropriately after the reversion of grassland desertification to maintain self-renewal capacity. They engage in illegal grazing for their own interest while expressing positive attitudes towards the survival of grasslands. Many studies indicate that after degraded grassland is restored, it should be sustainably grazed. A positive feedback relationship between plant growth and livestock feed can then be gradually established. Long-term prohibition of grazing is not conducive to the regeneration of grasslands [36,37]. In fact, after the implementation of the GBP, despite some illegal grazing, the overall pressure on grasslands was reduced compared with periods with no government supervision. Grassland desertification reversion in Yanchi County is the result of the interaction between the GBP and farmers' illegal grazing behavior.

\section{Conclusions}

This case study highlights changes in the perception of farmers over 10 years of GBP implementation. Knowledge of the policy and economic background of the study area gave us a preliminary understanding of the underlying causes of these changes. Farmers' answers inevitably reflect strong emotions towards the long-term implementation of the GBP. Even so, the results can reflect farmers' ideas to a certain extent via the comprehensive analysis of the data over several years. Additionally, the results provide a reference for subsequent rational policy formulation. 
As can be seen from the response of farmers to the GBP, ecological awareness of farmers tends to be short term. In areas with a degraded environment, farmers were eager to implement policies to improve the environment and recognized the positive impact of the GBP. However, as conditions improved, farmers' recognition and acceptance attitudes toward the GBP became negative. Although farmers recognize the effect of the GBP, they have little understanding of the long-term process of environmental governance. As can be seen from the attitudes of farmers toward the GBP and their ecological awareness, they are more inclined to value short-term economic interests than ecological protection.

As the direct users of grassland, farmers have a small farmers' consciousness, but they are sensitive to the perception of the quality of resources. A good ecological policy should take into account the ecological environment and the income of the farmers. Therefore, the formulation of future policies should take into account the views of those who will be most directly affected by its implementation. Given that farmers are driven by economic interests, the government should formulate corresponding incentive mechanisms, such as grazing fees or payments based on the provision of ecosystem services.

This article is a preliminary study, and a follow-up study should include controlled experiments to explore ways to motivate farmers and realize the sustainable management and utilization of the grassland.

Acknowledgments: This work has been financially supported by the National Natural Science Foundation of China (No. 41471436 and No. 41601587) and the National Key R\&D Program (2016YFC0500909). The comments and suggestions of the anonymous referees are appreciated.

Author Contributions: Yong Chen contributed to the data collection, data processing, and drafting of the paper; Lihua Zhou conceived and designed the study, and revised the paper.

Conflicts of Interest: The authors declare no conflict of interest.

\section{Appendix A}

Table A1. Mann-Whitney U Test.

\begin{tabular}{cccc}
\hline Asymp. Sig. (Two-Tailed) & 2003-2004 & 2007-2008 & 2011-2012 \\
\hline $2003-2004$ & - & $0.000^{* *}$ & $0.000^{* * *}$ \\
$2007-2008$ & & - & 0.541 \\
$2011-2012$ & & - \\
\hline * and ** are significant at $p<0.05$ and $p<0.01$, respectively.
\end{tabular}

Table A2. Mann-Whitney U Test.

\begin{tabular}{cccc}
\hline Asymp. Sig. (Two-Tailed) & 2003-2004 & 2007-2008 & 2011-2012 \\
\hline $2003-2004$ & - & 0.195 & 0.301 \\
$2007-2008$ & & - & 0.764 \\
2011-2012 & & & - \\
\hline
\end{tabular}

Table A3. Mann-Whitney U Test.

\begin{tabular}{cccc}
\hline Asymp. Sig. (Two-Tailed) & 2003-2004 & 2007-2008 & 2011-2012 \\
\hline 2003-2004 & - & $0.000^{* *}$ & $0.000^{* *}$ \\
2007-2008 & & - & 0.109 \\
2011-2012 & & - \\
\hline * and ** are significant at $p<0.05$ and $p<0.01$, respectively.
\end{tabular}


Table A4. Mann-Whitney U Test.

\begin{tabular}{cccc}
\hline Asymp. Sig. (Two-Tailed) & 2003-2004 & 2007-2008 & 2011-2012 \\
\hline 2003-2004 & - & $0.032^{*}$ & $0.000^{* *}$ \\
2007-2008 & & - & 0.093 \\
2011-2012 & & - \\
\hline * and ${ }^{* *}$ are significant at $p<0.05$ and $p<0.01$, respectively.
\end{tabular}

Table A5. Mann-Whitney U Test.

\begin{tabular}{cccc}
\hline Asymp. Sig. (Two-Tailed) & 2003-2004 & 2007-2008 & 2011-2012 \\
\hline $2003-2004$ & - & 0.152 & $0.000^{* *}$ \\
$2007-2008$ & & - & 0.541 \\
$2011-2012$ & & - \\
\hline * and ** are significant at $p<0.05$ and $p<0.01$, respectively.
\end{tabular}

Table A6. Mann-Whitney U Test.

\begin{tabular}{cccc}
\hline Asymp. Sig. (Two-Tailed) & 2003-2004 & 2007-2008 & 2011-2012 \\
\hline $2003-2004$ & - & 0.266 & 0.686 \\
$2007-2008$ & & - & 0.446 \\
$2011-2012$ & & & - \\
\hline
\end{tabular}

\section{References}

1. Dong, S.K.; Gao, H.W.; Xu, G.C.; Hou, X.Y.; Long, R.J.; Kang, M.Y.; Lassoie, J.P. Farmer and professional attitudes to the large-scale ban on livestock grazing of grasslands in China. Environ. Conserv. 2007, 34, 246-254. [CrossRef]

2. UNEP. One Planet Many People: Atlas of Our Changing Environment; Division of Early Warning and Assessment (DEWA) United Nations Environment Program (UNEP): Nairobi, Kenya, 2005; p. 336.

3. Chen, Y.; Wang, T.; Zhou, L.H.; Liu, N.; Huang, S. Effect of prohibiting grazing policy in northern China: A case study of Yanchi County. Environ. Earth Sci. 2014, 72, 67-77. [CrossRef]

4. Fan, M.; Li, Y.; Li, W. Solving one problem by creating a bigger one: The consequences of ecological resettlement for grassland restoration and poverty alleviation in Northwestern China. Land Use Policy 2015, 42, 124-130. [CrossRef]

5. Fernandez-Gimenez, M.E.; Le Febre, S. Mobility in pastoral systems: Dynamic flux or downward trend? Int. J. Sustain. Dev. World Ecol. 2006, 13, 341-362. [CrossRef]

6. Nelson, F. Natural conservationists? Evaluating the impact of pastoralist land use practices on Tanzania's wildlife economy. Pastoralism 2012, 2, 1-19. [CrossRef]

7. Song, N.P.; Zhang, F.R. Re-evaluation on the "Food for the program" policy and its impact on environment (in Chinese). Econ. Geogr. 2006, 26, 628-631.

8. Ren, J.Z. Grazing, the basic form of grassland ecosystem and its transformation. J. Nat. Resour. 2012, 27, 1259-1275. (In Chinese)

9. Akiyama, T.; Kawamura, K. Grassland degradation in China: Methods of monitoring, management and restoration. Grassl. Sci. 2007, 53,1-17. [CrossRef]

10. Wang, H.; Zhou, X.L.; Wan, C.G.; Fu, H.; Zhang, F.; Ren, J.Z. Eco-environmental degradation in the northeastern margin of the Qinghai-Tibetan Plateau and comprehensive ecological protection planning. Environ. Geol. 2008, 55, 1135-1147. [CrossRef]

11. Banks, T.; Richard, C.; Ping, L.; Yan, Z.L. Community-based grassland management in western China rationale, pilot project experience, and policy implications. Mt. Res. Dev. 2003, 23, 132-140. [CrossRef]

12. Ge, Q.S.; Zhao, M.C.; Zheng, J.Y. Land Use Change of China during the 20th Century. Acta Geogr. Sin. 2000, 55, 698-706. (In Chinese) 
13. Su, Y.Z.; Li, Y.L.; Cui, J.Y.; Zhao, W.Z. Influences of continuous grazing and livestock exclusion on soil properties in a degraded sandy grassland, Inner Mongolia, northern China. Catena 2005, 59, 267-278.

14. Chen, X.H.; Duan, Z.H. Changes in soil physical and chemical properties during reversal of desertification in Yanchi County of Ningxia Hui autonomous region, China. Environ. Geol. 2009, 57, 975-985. [CrossRef]

15. Wu, G.L.; Liu, Z.H.; Zhang, L.; Chen, J.M.; Hu, T.M. Long-term fencing improved soil properties and soil organic carbon storage in an alpine swamp meadow of western China. Plant Soil 2010, 332, 331-337. [CrossRef]

16. Zhao, S.; Zhang, J.N.; Lai, X.; Yang, D.L.; Zhao, J.N. Effects of grazing and fencing on soil enzyme activity and soil physicochemical properties in stipa steppe in Hulunbeier, Inner Mongolia. Chin. J. Grassl. 2011, 33, 71-76. (In Chinese)

17. Song, N.P.; Zhang, F.R.; Li, B.G.; Chen, H.W.; Yao, H.M.; Cao, L.X. Prohibiting graze policy and its effect. J. Nat. Resour. 2004, 19, 316-323. (In Chinese)

18. Zheng, W.; Dong, Q.M.; Li, S.X.; Shi, J.J.; Liu, Y.; Hou, X.K.; Song, L. Dynamics of plant community characteristics of alpine steppe under enclosure around Qinghai Lake. Pratacultural Sci. 2014, 31, 1126-1130. (In Chinese)

19. Yeh, E.T. Green governmentality and pastoralism in western China: Converting pastures to grasslands. Nomadic Peoples 2005, 9, 9-30. [CrossRef]

20. Foggin, J.M. Depopulating the Tibetan grasslands: National policies and perspectives for the future of Tibetan herders in Qinghai Province, China. Mt. Res. Dev. 2008, 28, 26-31. [CrossRef]

21. Yu, L.; Farrell, K.N. Individualized pastureland use: Responses of herders to institutional arrangements in pastoral China. Hum. Ecol. 2013, 41, 759-771. [CrossRef]

22. Luo, M.; Li, G. Analysis of effects of different operation patterns of returning farmland to forest (grass) on rural economy-A case of Wuqi County, China. Asian Agric. Res. 2010, 2, 5-9.

23. Liu, Y.H.; Tao, Y.G.; Yang, W.; Song, N.P. An analysis on input-output of animal raising before and after prohibiting grazing in ecotone-taking Yanchi County of Ningxia Hui Autonomous Region as an Example. J. Arid Land Resour. Environ. 2008, 22, 176-180. (In Chinese)

24. Wei, Y.P.; Chen, D.; White, R.E.; Willett, I.R.; Edis, R.; Langford, J. Farmers' perception of environmental degradation and their adoption of improved management practices in Alxa, China. Land Degrad. Dev. 2009, 20, 336-346. [CrossRef]

25. Wang, Y.; Feng, Q.; Chen, L.J.; Yu, T.F. Significance and effect of ecological rehabilitation project in inland river basins in northwest China. Environ. Manag. 2013, 52, 209-220. [CrossRef] [PubMed]

26. Berkes, F.; Colding, J.; Folke, C. Rediscovery of traditional ecological knowledge as adaptive management. Ecol. Appl. 2000, 10, 1251-1262. [CrossRef]

27. Mairota, P.; Leronni, V.; Xi, W.; Mladenoff, D.J.; Nagendra, H. Using spatial simulations of habitat modification for adaptive management of protected areas: Mediterranean grassland modification by woody plant encroachment. Environ. Conserv. 2014, 41, 144-156. [CrossRef]

28. McCaig, A.E.; Glover, L.A.; Prosser, J.I. Numerical analysis of grassland bacterial community structure under different land management regimens by using $16 \mathrm{~S}$ ribosomal DNA sequence data and denaturing gradient gel electrophoresis banding patterns. Appl. Environ. Microbiol. 2001, 67, 4554-4559. [CrossRef] [PubMed]

29. Cox, M. Modern disturbances to a long-lasting community-based resource management system: The Taos Valley acequias. Glob. Environ. Chang. 2014, 24, 213-222. [CrossRef]

30. Gold, J.R. An Introduction to Behavioural Geography; Oxford University Press: New York, NY, USA, $1980 ;$ p. 42.

31. Atteh, O.D. Nigerian farmers' perception of pests and pesticides. Int. J. Trop. Insect Sci. 1984, 5, $213-220$. [CrossRef]

32. Gasson, R.; Potter, C. Conservation through land diversion: A survey of farmers' attitudes. J. Agric. Econ. 1988, 39, 340-351. [CrossRef]

33. Whitby, M. Incentives for Countryside Management: The Case of Environmentally Sensitive Areas; CAB International: Wallingford, UK, 1994; pp. 253-271.

34. Cary, J.W.; Wilkinson, R.L. Perceived profitability and farmers' conservation behaviour. J. Agric. Econ. 1997, 48, 13-21. [CrossRef] 
35. Hardin, G. The Tragedy of the Commons. J. Nat. Resour. Policy Res. 2009, 1, 243-253. [CrossRef]

36. Rong, Y.P.; Zhao, M.L.; Han, G.D. Principle and Technology of Grassland Resource Sustainable Utilization; Chemical Industry Press: Beijing, China, 2004.

37. Yang, X.H.; Zhang, K.B.; Hou, R.P. Impacts of exclusion on vegetative features and above ground biomass in semi arid degraded rangeland. Ecol. Environ. 2005, 14, 730-734.

(c) 2016 by the authors; licensee MDPI, Basel, Switzerland. This article is an open access article distributed under the terms and conditions of the Creative Commons Attribution (CC-BY) license (http:/ / creativecommons.org/licenses/by/4.0/). 